\title{
Resveratrol prevents nanoparticles-induced inflammation and oxidative stress via downregulation of PKC-a and NADPH oxidase in lung epithelial A549 cells
}

Hung-Te Hsu ${ }^{1,2}$, Yu-Ting Tseng ${ }^{3}$, Wen-Jhe Wong ${ }^{3}$, Chi-Ming Liü ${ }^{4}$ and Yi-Ching Lo ${ }^{3 *}$

\begin{abstract}
Background: Exposure to carbon black nanoparticles (CBNPs), a well-known industrial production, promotes pulmonary toxicity through inflammation and oxidative stress. Recent studies show that some polyphenols exert their antioxidant properties through regulation of protein kinase C-a (PKC-a) and NADPH oxidase (Nox) signaling. Resveratrol, a dietary polyphenol in fruits, possesses various health beneficial effects including anti-inflammatory and antioxidative properties. In this study, we aimed to elucidate the involvement of PKC-a and Nox in CBNPs-induced inflammation and oxidative stress, and to investigate the protective effects of resveratrol on CBNP-induced inflammation and oxidative stress in human lung epithelial A549 cells.

Methods: The production of reactive oxygen species (ROS) and the change of mitochondrial membrane potential $\left(\Delta \psi_{\mathrm{m}}\right)$ were measured by flow cytometry. Nitric oxide $(\mathrm{NO})$ was measured using the Griess reagent, and prostaglandin $\mathrm{E}_{2}\left(\mathrm{PGE}_{2}\right)$ production was detected by ELISA, while protein expressions were measured by Western blotting analysis.

Results: In lung epithelial A549 cells, CBNPs significantly enhanced oxidative stress by upregulation of Nox2 and membrane expression of p67 ${ }^{\text {phox }}$ accompanied with increase of ROS production. CBNPs also increased inflammatory factors, including iNOS, COX-2, NO and PGE 2 . However, resveratrol attenuated the above effects induced by CBNPs in A549 cells; additionally, CBNPs-induced activation of PKC-a was observed. We found that PKC-a inhibitor (Gö6976) could attenuate CBNPs-induced inflammation by down-regulation of ROS, NO and PGE 2 production in A549 cells, suggesting PKC-a might be involved in CBNPs-induced oxidative stress and inflammation. Our results also found resveratrol was able to inhibit protein expression of PKC-a induced by CBNPs. Moreover, ROS scavenger (NAC) and Nox inhibitor (DPI) attenuated CBNPs-induced expressions of iNOS and COX-2. DPI could also attenuate CBNPs-induced $\mathrm{ROS}, \mathrm{NO}$ and $\mathrm{PGE}_{2}$ production.
\end{abstract}

Conclusions: Resveratrol attenuated CBNPs-induced oxidative and inflammatory factors in lung epithelial A549 cells, at least in part via inhibiting PKC-a- and Nox-related signaling.

Keywords: Nanoparticles, Resveratrol, PKC-a, NADPH oxidase, Inflammation, Oxidative stress

\footnotetext{
* Correspondence: yichlo@kmu.edu.tw

${ }^{3}$ Department of Pharmacology, School of Medicine, College of Medicine,

Kaohsiung Medical University, 100 Shih-Chuan 1st Road, Kaohsiung 80708,

Taiwan

Full list of author information is available at the end of the article
}

(c) The Author(s). 2018 Open Access This article is distributed under the terms of the Creative Commons Attribution 4.0 International License (http://creativecommons.org/licenses/by/4.0/) which permits unrestricted use, distribution, and reproduction in any medium, provided you give appropriate credit to the original author(s) and the source, provide a link to the Creative Commons license, and indicate if changes were made. The Creative Commons Public Domain Dedication waiver (http://creativecommons.org/publicdomain/zero/1.0/) applies to the data made available in this article, unless otherwise stated. 


\section{Background}

Nanoparticles (NPs) are defined as particles with any external dimension, internal structure, or surface structure in the nanoscale, approximately 1 to $100 \mathrm{~nm}$ [1]. NPs have been widely used in various commercial products such as medicine, cosmetic, and biotechnology etc., and can be found in many different environmental exposures. NPs-induced inflammation is associated with multiple diverse cardiopulmonary diseases because of their unique toxic properties. The NPs can easily enter the lungs during respiration due to their tiny size with a diameter less than $100 \mathrm{~nm}$ [2], subsequently inducing apoptosis and pro-inflammatory reaction in lung epithelial cells [3].

Carbon black nanoparticles (CBNPs) are one of the most used nanomaterials, which can interact with various biological systems and affect specific cellular function [4-6]. Till now, research on assessment of human exposure to CBNPs is scant. However, while CBNPs act as a core component of many ultrafine pollutants, the general public exposure is unpredictable. CBNPs can damage different organ systems by different exposure routes, and pulmonary inhalation is known as a major route of CBNPs exposure as CBNPs can impair the respiratory system leading to lung inflammation and fibrosis [7-9]. Exposure to CBNPs is known to induce lung inflammation in vivo $[10,11]$, and possesses the potential to generate reactive oxygen species (ROS) and inflammatory factors [12-16]. It has been suggested that CBNPs induce apoptosis by a ROS-dependent mitochondrial pathway in bronchial epithelial cells [13], and induce inflammatory response through ROS-NFKB pathway in macrophages [14]. Also, ERK MAP kinase and p38 MAP kinase might be involved in CBNPs-induced ROS production in alveolar macrophage [12].

Protein kinase $\mathrm{C}$ (PKC) activation has been identified to play a critical role in inflammation and oxidative stress. The PKC- $\alpha$ suppression also inhibited MMP-9 and COX-2 expression in human monocytes [17]. An enzyme which is well-known to be involved in signal transduction associated with inflammation and oxidative stress is the NADPH oxidase (Nox). A crosstalk between PKC and Nox has been reported for instance, in human airway epithelial cells, where PKC activation induced Nox-dependent ROS production [18]. In rat brain astrocytes, it has also been observed that bradykinin-induced inflammation via activation of PKC- $\alpha$ mediated Nox2/ROS signaling [19]. Recently, the NPs-induced Nox2 activation in macrophages has been reported [20]. Lung epithelial cells in the respiratory tract are the first barrier in contact with these inhalable NPs, and A549 human lung epithelial cells have been wildly used for studying NPs-induced cytotoxicity [21-23]; accordingly, in this study, we further investigated the role of PKC- $\alpha$ and Nox activation in CBNPs-induced inflammation on A549 cells.
A growing amount of evidence has demonstrated that inflammatory processes and particle-associated oxidative stress play major roles in particle-induced diseases. Such evidence is addressing a growing interest toward anti-inflammatory agents and anti-oxidants as preventive or curative treatments of environmentally-induced lung inflammation. Therefore, in this study, a well-known anti-inflammatory and anti-oxidative agent, resveratrol, was examined for its protective effects against nanoparticle toxicity. Resveratrol is a dietary polyphenol in fruits and food products that blocks the action of LPS-induced inflammatory mediators, including NO, PGE 2 , TNF- $\alpha$, and IL- $1 \beta$ through PI3K/Akt activation in RAW264.7 cells [24] and decreases cigarette smoke-induced ROS production in keratinocytes [25]. The protective effects and mechanisms of resveratrol on CBNPs-induced inflammation and ROS production were evaluated in this study.

The present study highlights the molecular mechanism of CBNPs-activated PKC- $\alpha$ and Nox linking the NPs-induced oxidative stress and inflammation, exploring the preventive molecular strategy against NPs-induced inflammation.

\section{Methods \\ Materials}

Resveratrol, bovine serum albumin (BSA), apocynin, diphenylene iodonium (DPI), N-acetyl cysteine (NAC), L-NG-Nitroarginine Methyl Ester (L-NAME), dimethyl sulfoxide (DMSO), 2',7' -dichloro-dihydrofluorescein diacetate ( $\left.\mathrm{H}_{2} \mathrm{DCF}-\mathrm{DA}\right), 12-(2-C y a n o e t h y l)-6,7,12,13$-tetrahydro-13-methyl-5-oxo-5H-indolo(2,3-a)pyrrolo(3,4-c)-carbazole (Gö6976), (+)-5-methyl-10,11-dihydro-5H-dibenzo [a,d] cyclohepten-5,10-imine maleate (MK-801), verapamil, 3-(4,5-dimethylthiazol- 2-yl)-2,5-diphenyltetrazolium bromide (MTT), Hoechst 33,342, Triton X-100, and mouse antibody against $\beta$-actin and iNOS were obtained from Sigma-Aldrich (St. Louis, MO, USA). Dulbecco's modified Eagle's medium (DMEM), fetal bovine serum (FBS), penicillin, amphotericin B, streptomycin, trypsin-EDTA, and 5,5',6,6'-tetrachloro- 1,1',3,3' -tetraethyl benzimidazolylcarbocyanine iodide (JC-1) were obtained from Invitrogen (Carlsbad, CA, USA). All materials for SDS-PAGE were obtained from Bio-Rad (Hercules, CA, USA). NS-398, mouse antibodies against COX-2, rabbit antibody against PKC- $\alpha$, p $67^{\text {phox }}$, and all horseradish peroxidase-conjugated secondary antibodies were obtained from Santa Cruz Biotechnology (Santa Cruz, CA, USA). Mouse antibody against Nox2 was obtained from BD Bioscience (San Jose, CA, USA). Enhanced chemiluminescence reagent and polyvinylidene difluoride (PVDF) membranes were purchased from PerkinElmer Life and Analytical Sciences (Boston, MA, USA). The LDH cytotoxicity assay kit was purchased from G-Biosciences (St. Louis, MO, USA). 


\section{Particle preparation}

The CBNPs (Printex90 ${ }^{\circ}, 14 \mathrm{~nm}$ ) were obtained from Evonik Industries/Degussa (Frankfurt, Germany). Stock suspensions of the CBNPs were made at a concentration of $1 \mathrm{mg} / \mathrm{mL}$ in DMEM, sonicated for $30 \mathrm{~min}$ before used.

\section{Cell culture}

Human epithelial carcinoma cell line (A549) was purchase from Food Industry Research and Development Institute (Hsin-Chu, Taiwan). Cells were cultured in DMEM containing $10 \%(v / \mathrm{v})$ heat-inactivated FBS, $2 \mathrm{mM}$ glutamine, $100 \mathrm{U} / \mathrm{mL}$ penicillin, $100 \mathrm{mg} / \mathrm{mL}$ streptomycin, and $0.25 \mathrm{mg} / \mathrm{mL}$ amphotericin $\mathrm{B}$ at $37{ }^{\circ} \mathrm{C}$ in a humidified incubator under $5 \% \mathrm{CO}_{2}$ and $95 \%$ air.

\section{Drug treatment}

To investigate the effects of CBNPs on A549 cells, cells were treated with CBNPs $(1-100 \mu \mathrm{g} / \mathrm{mL})$ for $24 \mathrm{~h}$. To investigate the mechanisms of CBNPs-induced inflammation and oxidative stress, cells were pre-treated with verapamil (100 $\mu \mathrm{M})$, MK801 (100 $\mu \mathrm{M})$, Gö6976 (10 $\mu \mathrm{M})$, DPI $(10 \mu \mathrm{M})$, apocynin $(500 \mu \mathrm{M})$, NAC $(5 \mathrm{mM})$, L-NAME $(50 \mu \mathrm{M})$, or NS398 $(1 \mu \mathrm{M})$ for $1 \mathrm{~h}$ before addition of CBNPs $(25 \mu \mathrm{g} / \mathrm{mL})$ for $24 \mathrm{~h}$. To investigate the protective effects of resveratrol in CBNPs-treated A549 cells, cells were pre-treated with resveratrol $(1,5$, and $10 \mu \mathrm{M})$ for $1 \mathrm{~h}$ before addition of CBNPs $(25 \mu \mathrm{g} / \mathrm{mL})$ for $24 \mathrm{~h}$. The control group in this study were cells without any treatment.

\section{Determination of cell viability}

The cell viability was determined by MTT (3-(4,5-Dimethylthiazol-2-yl)-2,5-diphenyl tetrazolium bromide) assay and lactate dehydrogenase (LDH) assay as previous described [26]. The principle of MTT assay is based on the cleavage of tetrazolium ring of MTT by dehydrogenases in active mitochondria of living cells as an estimate on cell viability. In MTT assay, cells were treated with CBNPs $(1-100 \mu \mathrm{g} /$ $\mathrm{mL})$ for $24 \mathrm{~h}$ or pre-treated with resveratrol $(1,5$, and $10 \mu \mathrm{M})$ for $1 \mathrm{~h}$ before addition of CBNPs $(25 \mu \mathrm{g} / \mathrm{mL})$ for
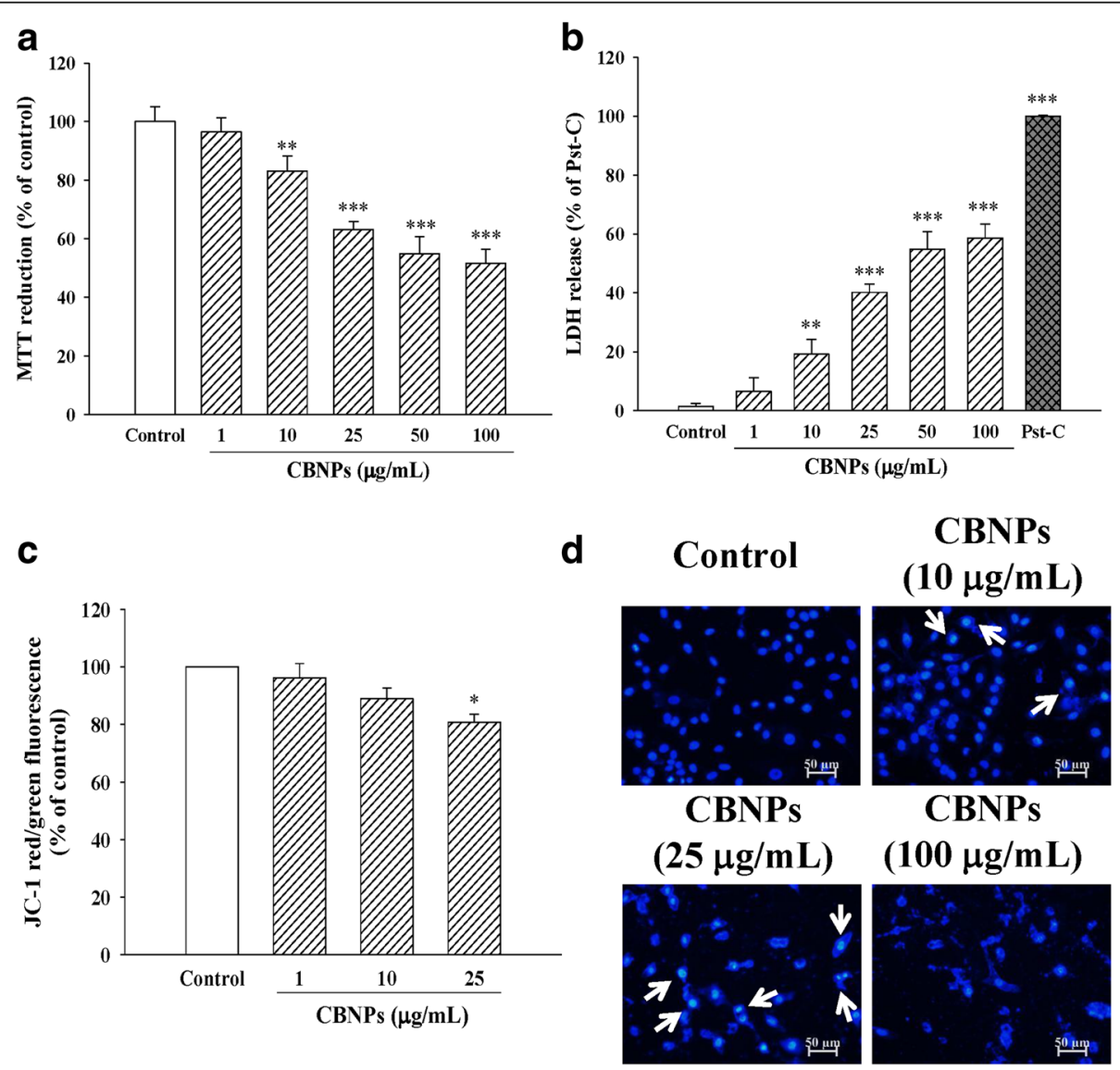

Fig. 1 Effects of CBNPs on cell viability assessed by MTT (a) and LDH (b) assay, and on changes of mitochondrial membrane potential $(\Delta \psi \mathrm{m})(\mathbf{c})$ and nuclear condensation (d) in A549 cells. $\Delta 4 \mathrm{~m}$ was measured by JC-1 staining and analyzed by a flow cytometer. Nuclear condensation (white arrow) was determined by Hoechst 33,342 and observed by a fluorescent microscope. Cells were treated with CBNPs for 24 h. Bars represent the mean \pm S.E.M. from six independent experiments. ${ }^{*} P<0.05,{ }^{* *} P<0.01,{ }^{* * *} P<0.001$ vs. control group (without any treatment). Scale bar $=50 \mu m$ 
$24 \mathrm{~h}$, the medium was replaced with MTT at a final concentration of $0.5 \mathrm{mg} / \mathrm{mL}$ for $3 \mathrm{~h}$ at $37{ }^{\circ} \mathrm{C}$ and $5 \% \mathrm{CO}_{2}$. The formazan crystals in the cells were solubilized with $100 \mu \mathrm{L}$ DMSO. Absorbance was read at $560 \mathrm{~nm}$ on a microplate reader. Besides, LDH is a soluble cytosolic enzyme in cells that can be released into culture medium when cell death occurs; therefore, the presence of this enzyme in the culture medium can be used as a cell death marker. In LDH assay, culture medium was collected and assayed for LDH activity using a cytotoxicity detection kit. Briefly, the release of LDH was measured with a coupled enzymatic reaction that results in the conversion of a tetrazolium salt into red-colored formazan. The amount of formazan formed correlated with LDH activity. The formazan product was measured with a microplate reader at $490 \mathrm{~nm}$.

\section{Measurement of mitochondrial membrane potential} $(\Delta \Psi \mathrm{m})$ and reactive oxygen species (ROS) production The change in $\Delta \Psi \mathrm{m}$ was evaluated by JC- 1 fluorescence staining assay [27] which was determined by the ratio between red and green fluorescence. The red JC-1 fluorescence were detected by excitation/emission at 540/ $570 \mathrm{~nm}$, and green JC-1 fluorescence were detected by excitation/emission at $495 / 520 \mathrm{~nm}$ by Coulter CyFlow Cytometer (Partec, Germany). The production of ROS was detected by fluorescence assay that involved $\mathrm{H}_{2}$ DCF-DA staining [28]. After $24 \mathrm{~h}$ of drug treatments, the A549 cells were stained with $10 \mu \mathrm{M} \mathrm{H} \mathrm{H}_{2}$ DCF-DA at $37{ }^{\circ} \mathrm{C}$. After 30 min of incubation, the A549 cells were detached by trypsin-EDTA and washed with PBS. One hundred thousand $\left(1 \times 10^{5}\right)$ cells were analyzed and the DCF fluorescence was detected by excitation at $495 \mathrm{~nm}$ and emission

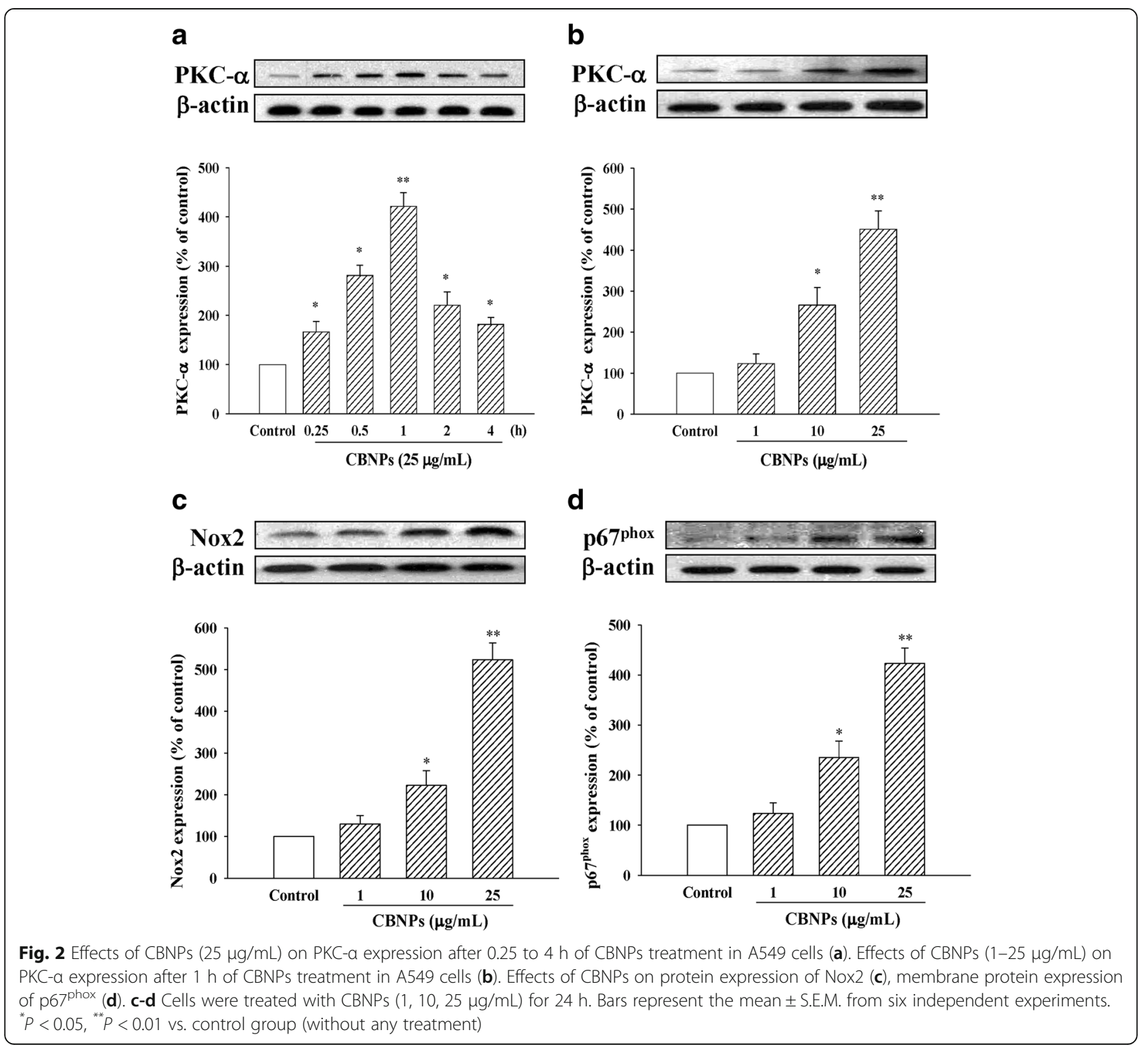


of $520 \mathrm{~nm}$ by Coulter CyFlow Cytometer (Partec, Germany).

\section{Measurement of nitric oxide and prostaglandin $E_{2}$}

Nitrite generation was an indicator of nitric oxide (NO) release measured using the Griess reagent (1\% sulfanilamide and $0.1 \% \mathrm{~N}-1$-naphthylethylenediamide in 5\% phosphoric acid) [29]. Briefly, the medium from treated cells was collected. and $50 \mu \mathrm{L}$ was incubated for $10 \mathrm{~min}$ at room temperature under dark conditions with $50 \mu \mathrm{L}$ of Griess reagent. The absorbance was measured at $540 \mathrm{~nm}$ (OD540) and the concentration was calculated using a sodium nitrite standard reference curve [29]. The $\mathrm{PGE}_{2}$ production in the supernatant was detected using EIA kit (Cayman Chemical, USA), following the manufacturer's guide [30]. Supernatant was collected

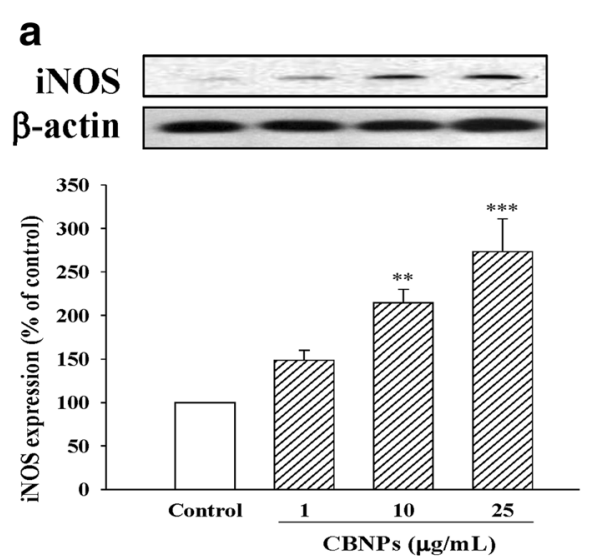

c
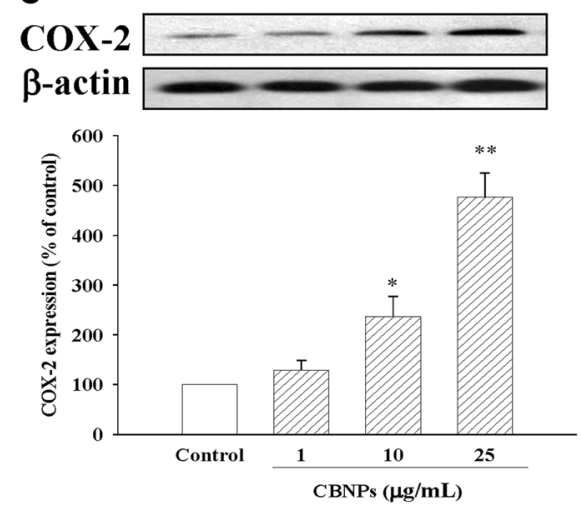

b

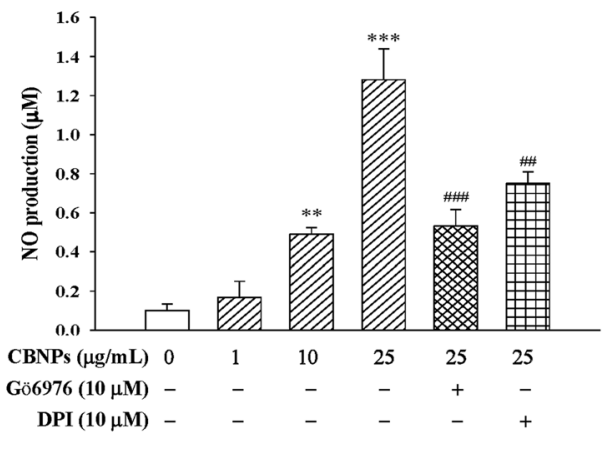

d

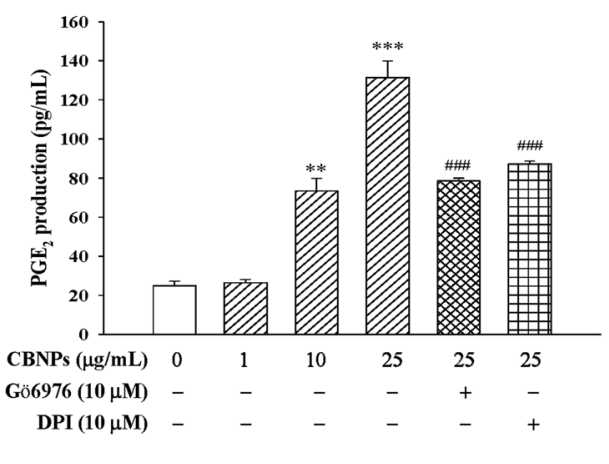

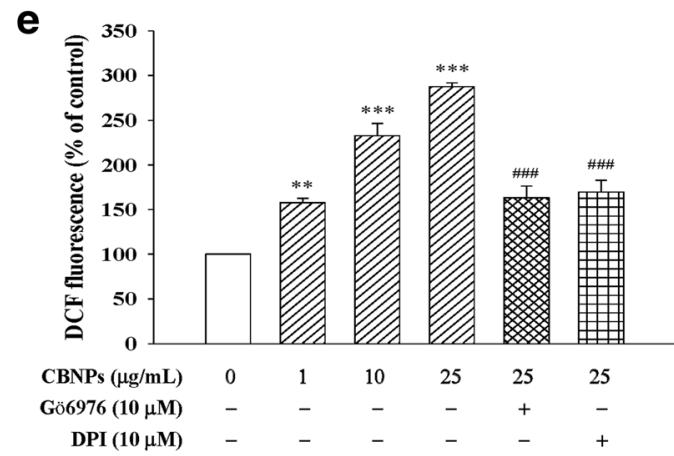

Fig. 3 Effects of CBNPs on iNOS expression (a), effects of Gö6976 or DPI on NO production (b), COX-2 expression (c), and effects of Gö6976 or DPI on PGE 2 production (d), and effects of Gö6976 or DPI on ROS production (e) in A549 cells. Cells were treated with CBNPs $(1,10,25 \mu \mathrm{g} / \mathrm{mL})$ for $24 \mathrm{~h}$ or pretreated with Gö6976 or DPI for $1 \mathrm{~h}$ respectively, and then treated with CBNPs $(1-25 \mu \mathrm{g} / \mathrm{mL})$ for $24 \mathrm{~h}$. ROS production was measured using $\mathrm{H}_{2} \mathrm{DCF}-\mathrm{DA}$ staining and detected the DCF fluorescence by flow cytometer. Bars represent the mean \pm S.E.M. from six independent experiments. ${ }^{*} P<0.05,{ }^{* *} P<0.01,{ }^{* * *} P<0.001$ vs. control group (without any treatment). ${ }^{\# \#} P<0.01,{ }^{\# \# \#} P<0.001$ vs. CBNPs (25 $\mu \mathrm{g} / \mathrm{mL}$ ) group 
after $24 \mathrm{~h}$ of CBNPs $(1,10$, or $25 \mu \mathrm{g} / \mathrm{mL})$ treatment with or without Gö6976 $(10 \mu \mathrm{M})$, DPI $(10 \mu \mathrm{M})$ or resveratrol $(1,5$, or $10 \mu \mathrm{M})$ pretreatment, and the absorbance measured at $405 \mathrm{~nm}$ (OD405).

\section{Immunocytochemistry}

After $24 \mathrm{~h}$ of CBNPs exposure, cells were washed with $\mathrm{PBS}$ and fixed with $4 \%$ paraformaldehyde for $30 \mathrm{~min}$, and further incubated in a permeabilizing solution $(0.1 \%$ Triton X-100) for 5 min. Cells were then stained with $5 \mu \mathrm{g} / \mathrm{mL}$ Hoechst 33,342 for 10 min to detect DNA condensation, and nuclear fragmentation, which were features of apoptotic cells
[31]. The cells were observed under fluorescence microscopy (Nikon, Japan).

\section{Western blotting analysis}

Western blotting analysis was used to determine protein expressions. After CBNPs $(1,10$, or $25 \mu \mathrm{g} / \mathrm{mL})$ treatment with or without verapamil $(100 \mu \mathrm{M})$, MK801 $(100 \mu \mathrm{M})$, Gö6976 $(10 \mu \mathrm{M})$, DPI $(10 \mu \mathrm{M})$, apocynin $(500 \mu \mathrm{M})$, NAC $(5 \mathrm{mM})$, L-NAME $(50 \mu \mathrm{M})$, NS398 $(1 \mu \mathrm{M})$, or resveratrol $(1,5$, or $10 \mu \mathrm{M})$ pretreatment, cytosolic or membrane protein extracts of A549 cells were collected by using lysis buffer (Thermo Scientific, Waltham, MA, USA) or commercial kit (BioVision, Mountain View, CA, USA)

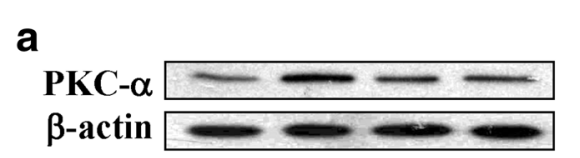

b
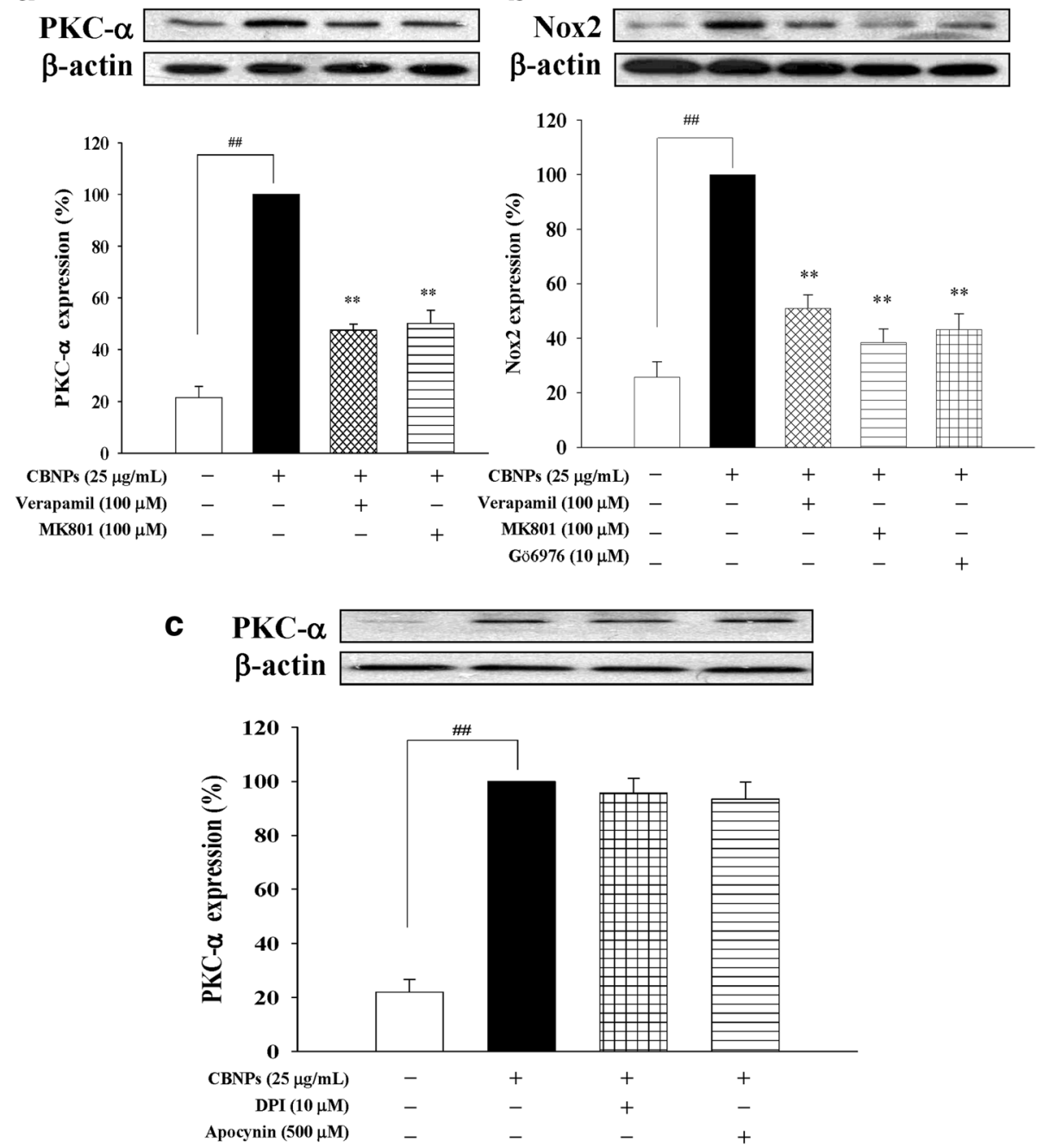

Fig. 4 a Effects of verapamil or MK801 on CBNPs-induced PKC-a activation in A549 cells. b Effects of verapamil, MK801, or Gö6976 on CBNPinduced Nox2 activation in A549 cells. c Effects of DPI or apocynin on CBNPs-induced PKC-a activation in A549 cells. Cell were pretreated with verapamil, MK801, Gö69761, DPI, or apocynin for 1 h, respectively, and then treated with CBNPs $(25 \mu \mathrm{g} / \mathrm{mL})$ for $1 \mathrm{~h}$ or $24 \mathrm{~h}$ for determination of PKC- $a$ and Nox, respectively. Bars represent the mean \pm S.E.M. from six independent experiments. ${ }^{\sharp \#} P<0.01$ vs. control group (without any treatment). ${ }^{* *} P<0.01$ vs. CBNPs $(25 \mu \mathrm{g} / \mathrm{mL})$ group 
respectively as described previously [30]. The lysates were centrifuged at $15000 \times \mathrm{g}$ for $30 \mathrm{~min}$ at $4{ }^{\circ} \mathrm{C}$ and the supernatant containing proteins was collected. The proteins were reversed by SDS-polyacrylamide gel electrophoresis after using the Bio-Rad protein assay kit to determine the total protein concentration, then the protein bands were transferred onto polyvinylidene difluoride (PVDF) membranes and incubated with TBST (50 mM Tris-HCl, pH 7.6, $150 \mathrm{mM} \mathrm{NaCl}, 0.1 \%$ Tween 20) containing 5\% non-fat milk for $1 \mathrm{~h}$ at room temperature to block the non-specific binding sites. Following that, the PVDF membranes were incubated overnight at $4{ }^{\circ} \mathrm{C}$ with one of the following specific primary antibodies: rabbit anti-PKC- $\alpha$ (1: 1000), rabbit anti-Nox2 (1: 1000), rabbit anti-p67 ${ }^{\text {phox }}$ (1: 1000), mouse anti-iNOS (1:500), goat anti-COX-2 (1: 1000), and mouse anti- $\beta$-actin $(1: 10,000)$. After six wash cycles with TBST at $5 \mathrm{~min}$ intervals, membranes were incubated with one of the following secondary antibodies: goat anti-rabbit IgG-HRP (1: 1000), goat anti-mouse IgG HRP (1: 1000), or donkey anti-goat IgG HRP (1: 5000) for $1 \mathrm{~h}$ at room temperature. After six wash cycles with TBST, the protein bands were stained with the enhanced chemiluminescence reagent. a
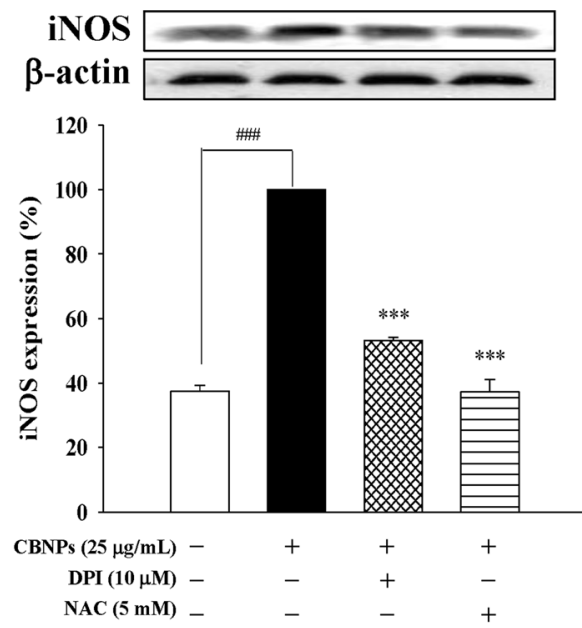

C

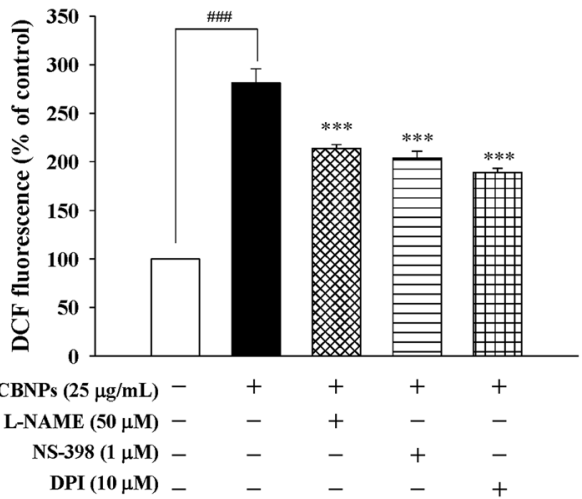

b
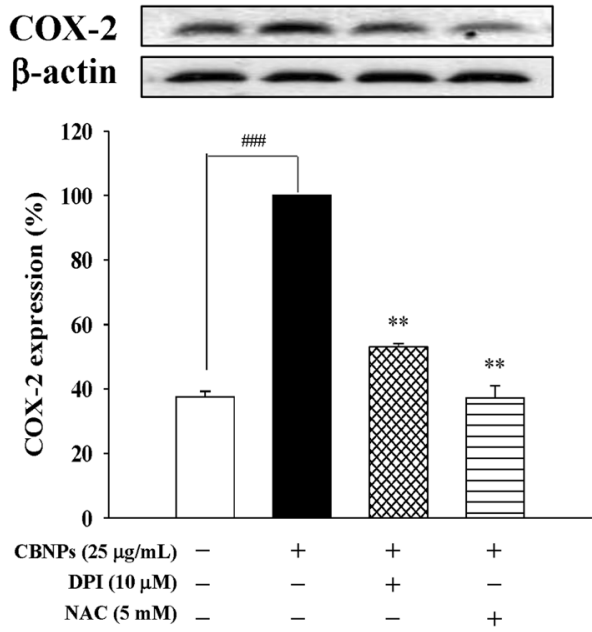

d
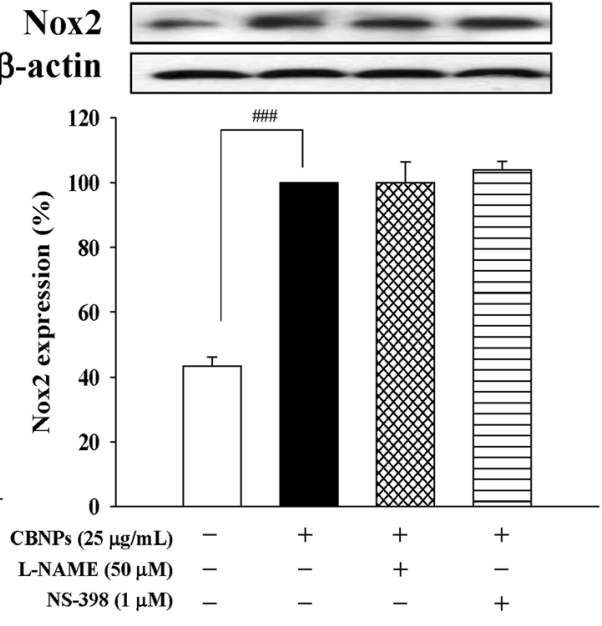

Fig. 5 Effects of DPI or NAC on CBNP-induced iNOS (a) and COX-2 (b) expression in A549 cells. $\mathbf{c}$ Effects of L-NAME, NS-398, or DPI on CBNP-induced ROS production in A549 cells. $\mathbf{d}$ Effects of L-NAME or NS-398 on CBNP-induced Nox2 activation in A549 cells. Cells were pretreated with DPI, NAC, L-NAME, or NS-398 $1 \mathrm{~h}$ before addition of CBNPs ( $25 \mu \mathrm{g} / \mathrm{mL}$ ) for $24 \mathrm{~h}$. ROS production was measured using $\mathrm{H}_{2}$ DCF-DA staining and detected the DCF fluorescence by flow cytometer. Bars represent the mean \pm S.E.M. from six independent experiments. ${ }^{\# \# \# P} P 0.001$ vs. control group (without any treatment). ${ }^{* *} P<0.01$,

${ }^{* * *} P<0.001$ vs. CBNPs $(25 \mu \mathrm{g} / \mathrm{mL})$ group 


\section{Statistical analysis}

Data are shown as the mean \pm standard error of the mean (S.E.M) from six independent experiments $(n=6)$. A one-way analysis of variance (ANOVA) followed by Tukey's test was used for all pair comparisons. A value of $P<0.05$ was considered as statistically significant. Data were analyzed with the Statistical Package for Social Sciences (SPSS, Chicago, IL, USA).

\section{Results}

CBNPs decrease cell viability with loss of mitochondrial membrane potential $\left(\Delta \Psi_{\mathrm{m}}\right)$ and increase of nuclear condensation in A549 cells

To examine the cytotoxic effects of CBNPs on lung epithelial cells, cultured A549 were treated with various concentrations of CBNPs for $24 \mathrm{~h}$. Results from MTT (Fig. 1a) and LDH (Fig. 1b) assay indicated that CBNPs $(10-100 \mu \mathrm{g} / \mathrm{mL})$ significantly decreased cell viability of A549 cells. CBNPs also decreased $\triangle \Psi \mathrm{m}$ of A549 cells (Fig. 1c). Moreover, CBNPs-induced nuclear condensation of A549 cells was observed by using Hoechst 33,342 staining (Fig. 1d).

\section{CBNPs activate PKC- $a /$ Nox pathway in A549 cells}

Next, we examined the effects of CBNPs on PKC- $\alpha$ and Nox activation. As shown in Fig. 2a, CBNPs produced its peak effect on PKC- $\alpha$ activation at $1 \mathrm{~h}(421.33 \pm 27.75 \%$ of control). Accordingly, cells were incubated with different concentrations $(1,10$ and $25 \mu \mathrm{g} / \mathrm{mL}$ ) of CBNPs for $1 \mathrm{~h}$, and the results suggested that CBNPs induced PKC- $\alpha$ activation occurred in a concentration-dependent manner (Fig. 2b). Also, CBNPs (10 and $25 \mu \mathrm{g} / \mathrm{mL}$ ) enhanced epithelial Nox2 expression (Fig. 2c) and induced $\mathrm{p} 67^{\text {phox }}$ membrane translocation (Fig. 2d).
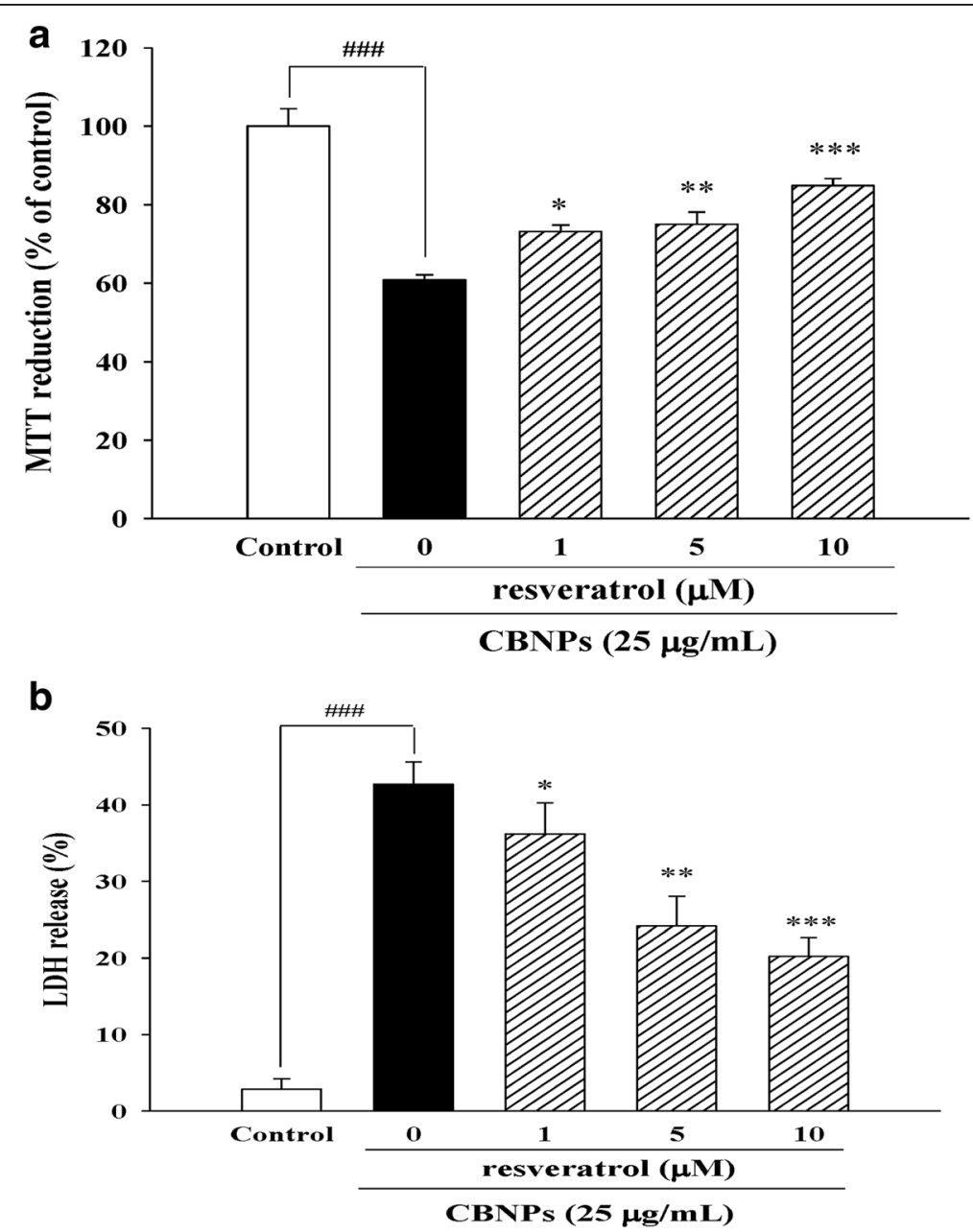

Fig. 6 Effects of resveratrol on cell viability in CBNPs-treated A549 cells. Cells were pre-treated with resveratrol for $1 \mathrm{~h}$ before addition of CBNPs $(25 \mu \mathrm{g} / \mathrm{mL})$ for $24 \mathrm{~h}$. Cell viability was measured by MTT (a) and LDH assay (b). Bars represent the mean \pm S.E.M. from six independent

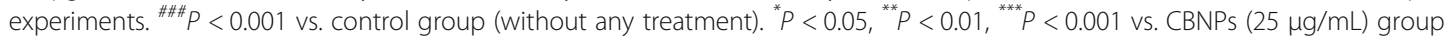


Roles of PKC- $a$ and Nox on CBNPs-induced inflammation and oxidative stress

As shown in Fig. 3, CBNPs up-regulated inflammatory protein expression of iNOS (Fig. 3a) and COX-2 (Fig. 3c), and increased their downstream products NO (Fig. 3b) and $\mathrm{PGE}_{2}$ (Fig. $3 \mathrm{~d}$ ) respectively. The CBNPs-induced ROS production was also measured by using $\mathrm{H}_{2}$ DCF-DA staining and detecting the DCF fluorescence. Results indicated that CBNPs significantly increased epithelial ROS production (Fig. 3e). We further examined the role of PKC- $\alpha$ and Nox on CBNPs-induced inflammation and oxidative stress via measuring $\mathrm{NO}, \mathrm{PGE}_{2}$, and ROS production. Results demonstrated that both PKC- $\alpha$ inhibitor Gö6976 $(10 \mu \mathrm{M})$ and Nox inhibitor DPI $(10 \mu \mathrm{M})$ attenuated CBNPs-induced production of $\mathrm{NO}$ (Fig. 3b) and $\mathrm{PGE}_{2}$ (Fig. 3d). CBNPs-induced production of ROS was also inhibited by Gö6976 and DPI pretreatment (Fig. 3e).
Roles of PKC-a on CBNPs-induced Nox activation

To clarify the role of PKC- $\alpha$ on CBNPs-induced Nox activation, L-type $\mathrm{Ca}^{2+}$ channel blocker verapamil, and NMDA receptor antagonist MK-801 were added to A549 cells $1 \mathrm{~h}$ before CBNPs $(25 \mu \mathrm{g} / \mathrm{mL})$ treatment. Results indicated that both verapamil and MK-801 treatments attenuated PKC- $\alpha$ expression induced by CBNPs (Fig. 4a). Moreover, PKC- $\alpha$ inhibition (by verapamil, MK-801, and Gö6976) attenuated CBNPs-induced Nox2 expression (Fig. 4b). However, Nox inhibitors (DPI and apocynin) could not attenuate PKC- $\alpha$ activation caused by CBNPs (Fig. 4c).

Roles of Nox activation and ROS production in CBNPsinduces inflammation

To examine the roles of Nox and ROS on CBNPs-induced inflammation, Nox inhibitor DPI and ROS scavenger NAC were used. The present results indicated that DPI

\section{a}
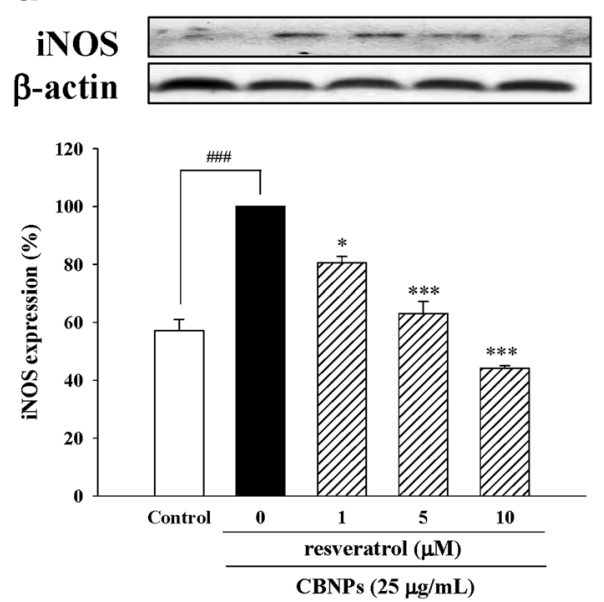

C
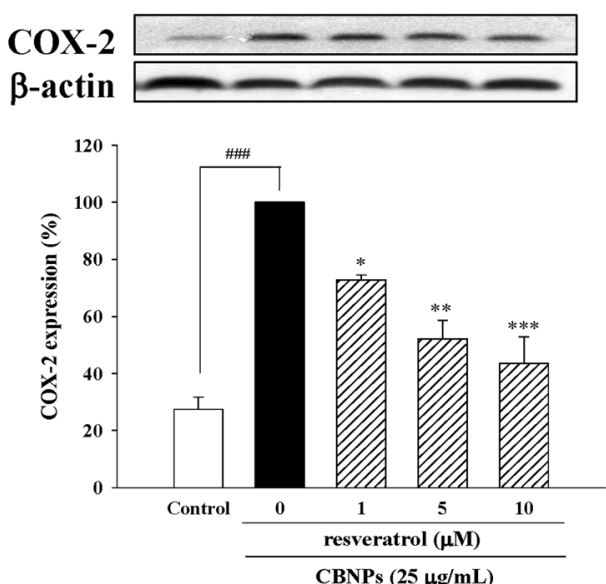

b

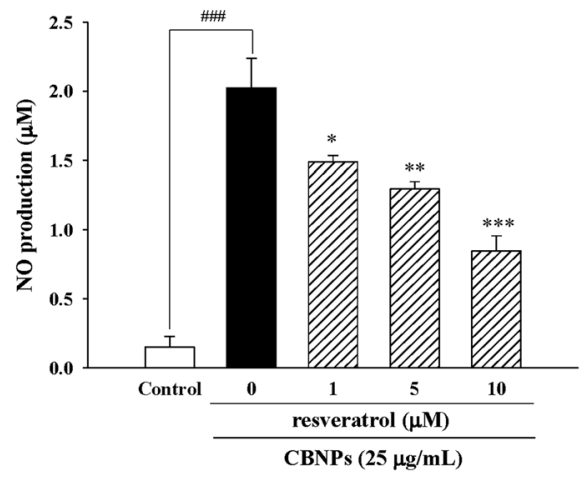

d

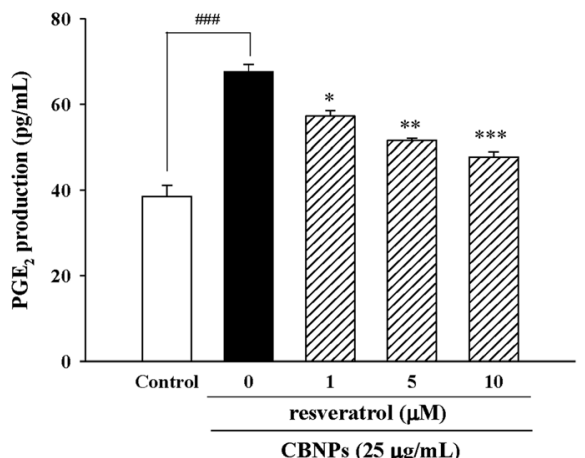

Fig. 7 Effects of resveratrol on iNOS expression (a), NO production (b), COX-2 expression (c), and PGE 2 production (d) in CBNPs-treated A549 cells. Cells were pre-treated with resveratrol for $1 \mathrm{~h}$ before addition of CBNPs $(25 \mu \mathrm{g} / \mathrm{mL})$ for $24 \mathrm{~h}$. Bars represent the mean \pm S.E.M. from six independent experiments. ${ }^{\# \#} P<0.001$ vs. control group (without any treatment). ${ }^{*} P<0.05,{ }^{* *} P<0.01,{ }^{* * *} P<0.001 \mathrm{vs}$. CBNPs (25 $\left.\mu \mathrm{g} / \mathrm{mL}\right) \mathrm{group}$ 
$(10 \mu \mathrm{M})$ could attenuate CBNPs-induced expression of iNOS (Fig. 5a) and COX-2 (Fig. 5b). Similarly, CBNPs-induced expression of iNOS and COX-2 could be attenuated by NAC ( $5 \mathrm{mM})$ pretreatment (Figs. $5 \mathrm{a}$ and $\mathrm{b})$. Moreover, CBNPs-induced ROS production could be attenuated by DPI, L-NAME (NOS inhibitor) and NS-398 (COX-2 inhibitor) (Fig. 5c). However, L-NAME and NS-398 could not significantly attenuate CBNPs-induced Nox2 activation (Fig. 5d).

\section{Resveratrol reduces CBNPs-induced cell death in A549 cells}

Further, we investigated the potential protective effects of the known anti-inflammatory and anti-oxidative agent, resveratrol, on CBNPs-induced epithelial cytotoxicity. A549 cells were treated with resveratrol for $1 \mathrm{~h}$ before the addition of CBNPs $(25 \mu \mathrm{g} / \mathrm{mL})$ for $24 \mathrm{~h}$. Results from MTT and LDH assays indicated that resveratrol decreased cytotoxicity induced by CBNPs (Figs.6a and b).

\section{Resveratrol protects A549 cells against CBNPs-induced inflammation in A549 cells}

We next evaluated the effects of resveratrol on CBNPs-induced epithelial inflammation. Results indicated resveratrol not only decreased iNOS expression (Fig. 7a) and NO production (Fig. 7b), but also decreased COX-2 expression (Fig. 7c) and $\mathrm{PGE}_{2}$ production (Fig. 7d) in CBNPs-treated A549 cells.

\section{Resveratrol reduce CBNPs-induced PKC- $a /$ Nox2/ROS activation in A549 cells}

We further investigated the protective effects of resveratrol on CBNPs-induced PKC- $\alpha$ expression, Nox2 activation and ROS production on A549 cells. Resveratrol attenuated PKC- $\alpha$ expression (Fig. 8a), Nox2 expression (Fig. 8b), p67 ${ }^{\text {phox }}$ membrane translocation (Fig. 8c), and ROS production (Fig. 8d) induced by CBNPs.

\section{Discussion}

The CBNPs are common air pollutants that are widely used in various commercial products as nano materials. CBNPs can readily suspend in the ambient atmosphere and cause airborne health issues when inhaled by humans due to their characteristically extreme small size, slight weight, and poor solubility. Bio-safety studies to provide data on CBNPs exposure are limited. Therefore, studies on mechanisms induced by CBNPs in human target cells would be helpful in preventing, identifying, and even treating the potential disorders caused by such particle exposure. The results generated by this study showed that PKC- $\alpha /$ Nox-mediated inflammation and oxidative stress contributed to CBNPs-induced toxicity in A549 cells.
Many studies have performed research on the cytotoxic effects of CBNPs [13, 32, 33]. A study on bronchial epithelial cells suggested that CBNPs induce ROS production, mitochondrial membrane potential loss, pro-apoptotic Bax activation, cytochrome $c$ release, and cell apoptosis [13]. The present results supported the previous study [13] that CBNPs caused mitochondrial membrane potential loss, nuclear condensation and cell death.

Inflammation and oxidative stress are closely associated with many pulmonary diseases [34, 35]. Increasing evidence shows that ROS production plays a major role in inflammatory processes [36, 37]. It is reported that CBNPs induce inflammatory response by significantly inducing ROS production, IL-6 expression, and NFKB signaling, leading to COX-2 and TNF- $\alpha$ expression in RAW264.7 cells [14]. Moreover, NAC, a well-known ROS scavenger, attenuates CBNPs-induced NFKB [38], suggesting that ROS production plays a critical role in CBNPs-induced inflammation. The results obtained in this topic further demonstrated that PKC- $\alpha$ inhibitor significantly inhibited CBNPs-induced inflammatory responses via decreasing ROS production and leading to downregulation of $\mathrm{NO}$ and $\mathrm{PGE}_{2}$ in $\mathrm{A} 549$ cells, suggesting the important role of $\mathrm{PKC}-\alpha$ in CBNPs-induced inflammatory pathways.

Nox activation plays an important role in ROS-mediated lung inflammation [39]. Our results demonstrated that CBNPs increased Nox2 expression and translocated its cytosolic subunit p67 $7^{\text {phox }}$ to the membrane in A549 cells. Nox inhibitor (DPI) has been reported for its protective effects against CBNPs via inhibiting ROS production [12]. Here, we further demonstrated that DPI not only inhibited ROS, but also decreased CBNPs-induced inflammatory factors iNOS/NO and COX-2/PGE 2 in A549 cells. Moreover, the present results showed that pretreatment of L-NAME or NS-398 could not significantly decrease CBNPs-induced Nox2 expression, suggesting CBNPs-induced Nox2 expression is not mediated via upregulation of iNOS and COX-2.

PKC plays a key role in different cellular signal transduction pathways [40]. It has been suggested as a master regulator of Nox activation [40, 41]. Activation of PKC- $\alpha$, a $\mathrm{Ca}^{2+}$-dependent PKC, increases ET-1-induced $\mathrm{COX}-2 / \mathrm{PGE}_{2}$ in mouse brain microvascular endothelial cells [42], and increases LPS-induced iNOS/NO in alveolar epithelial cells [43]. A previous study demonstrated that CBNPs might cause intracellular $\mathrm{Ca}^{2+}$ increase in MM6 human monocytic cells [44]. The present results also showed that verapamil (L-type calcium channel blocker) and MK-801 (NMDA receptor antagonist) inhibit CBNPs-induced PKC- $\alpha$ activation. Therefore, we focused on investigating the role of PKC- $\alpha$ in CBNPs-induced inflammation in A549 cells. Our results demonstrated CBNPs-induced production of $\mathrm{NO}, \mathrm{PGE}_{2}$, and ROS could be attenuated by Gö6976 (PKC- $\alpha$ inhibitor) pretreatment, suggesting that $\mathrm{PKC}-\alpha$ might play a 


\section{a}
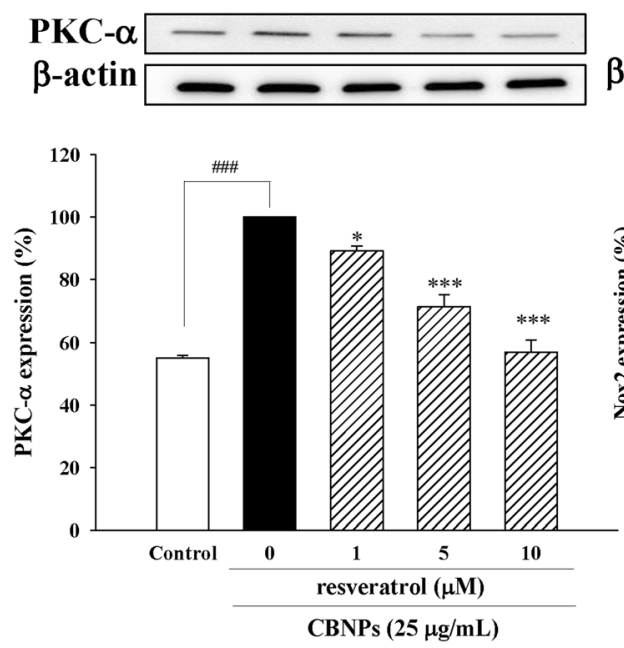

C
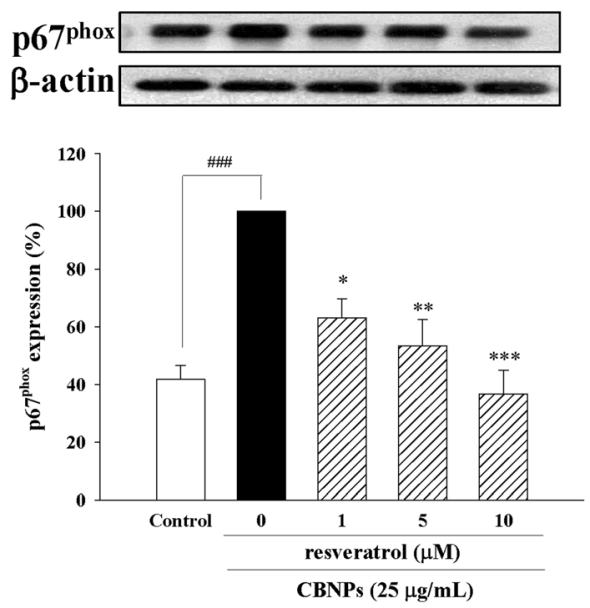

b
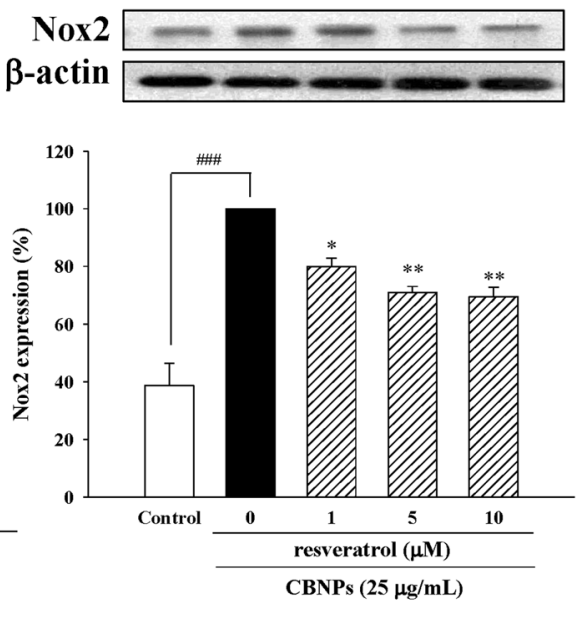

d

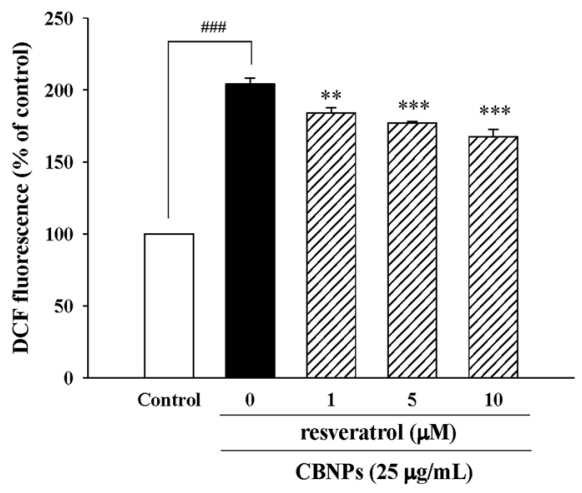

Fig. 8 Effects of resveratrol on PKC-a expression (a), Nox2 expression (b), p67 $7^{\text {phox }}$ membrane translocation (c), and ROS production (d) in CBNPs-treated A549 cells. Cells were pretreated with resveratrol for $1 \mathrm{~h}$ before addition of CBNPs $(25 \mu \mathrm{g} / \mathrm{mL})$ for $24 \mathrm{~h}$. ROS production was measured using $\mathrm{H}_{2} \mathrm{DCF}-\mathrm{DA}$

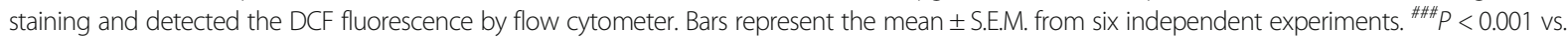
control group (without any treatment). ${ }^{*} P<0.05,{ }^{* *} P<0.01,{ }^{* * *} P<0.001$ vs. CBNPs $(25 \mu \mathrm{g} / \mathrm{mL})$ group

role in CBNPs-induced inflammation and oxidative stress. Moreover, the role of PKC- $\alpha$ in Nox-derived ROS production in pulmonary artery smooth muscle cells has been reported [45].

Therefore, we further evaluated the crosstalk between PKC- $\alpha$ and Nox in CBNPs-treated A549 cells. Our results indicated that inhibition of PKC- $\alpha$ by verapamil, MK801, and Gö6976 could inhibit CBNPs-induced Nox2 activation. However, inhibition of Nox by DPI and apocynin could not inhibit CBNPs-induced PKC- $\alpha$ activation. Taken together, PKC- $\alpha$-mediated Nox activation contributed to CBNPs-induced inflammation and oxidative stress.

Resveratrol is a natural antioxidant in red wine and possesses a wide range of pharmacological anti-inflammatory, antioxidative, and anti-apoptotic properties, et al. [25, 46-48]. Resveratrol has previously been reported to repress oxidative and inflammatory lung injury against cigarette smoke exposure in vivo [49], and cigarette smoke is known as one of the major source of CBNPs [50]. Moreover, the present study reveals the important role of PKC- $\alpha /$ Nox in CBNPs-mediated inflammation and oxidative stress. Resveratrol has been reported to attenuate PMA-induced oxidative burst in isolated human neutrophils via PKC- $\alpha$ activation [51]; additionally, resveratrol decreases high glucose-induced endothelial apoptosis via Nox/ROS inhibition [52]. Recently, resveratrol is suggested to inhibit particulate matter-induced COX-2/PGE 2 production in human fibroblast-like synoviocytes via attenuation of Nox/ROS/NF-kB [53]. 
However, the potential benefits of resveratrol on CBNPs-induced cytotoxicity have not yet been investigated. The present study further demonstrated resveratrol protected A549 cells against CBNPs-induced cytotoxicity. Moreover, resveratrol attenuated CBNPs-induced expression of inflammatory factors (iNOS/NO, COX-2/PGE ${ }_{2}$ ), and also inhibited Nox/ROS pathway in CBNPs-treated A549 cells. These results also suggest that fruits and food products containing resveratrol might provide health benefits to prevent NPs-induced inflammation.

\section{Conclusions}

In the present study, we demonstrated the important role of PKC- $\alpha$ and Nox on CBNPs-induced inflammation and oxidative stress in human epithelial cells and reveal the potential protective effects of resveratrol against CBNPs-induced cytotoxicity, suggesting drug or dietary products providing PKC- $\alpha /$ Nox inhibitory effects might inhibit NPs-induced lung inflammation.

\begin{abstract}
Abbreviations
CBNPs: Carbon black nanoparticles; COX-2: Cyclooxygenase-2; iNOS: Inducible nitric oxide synthase; LDH: Lactate dehydrogenase; MTT: 3-(4,5dimethylthiazol- 2-yl)-2,5-diphenyltetrazolium bromide; NO: Nitric oxide; Nox: NADPH oxidase; GGE $_{2}$ : Prostaglandin $E_{2} ;$ PKC-a: Protein kinase C-a; ROS: Reactive oxidase species; $\Delta \psi \mathrm{m}$ : Mitochondrial membrane potential
\end{abstract}

\section{Acknowledgements}

We thank Wan-Hsuan Chang and Chih-Cheng Lin for their assistance in cell preparations.

\section{Funding}

This study was supported by grants provided from National Science Council of Taiwan to Yi-Ching Lo [grant number: NSC 99-2320-B-037-023-MY3 and NSC102-2628- B-037-001-MY3], and from Kaohsiung Municipal Ta-Tung Hospital to Hung-Te Hsu [grant number: kmtth-104-051].

\section{Availability of data and materials}

The datasets used and/or analyzed during the current study are available from the corresponding author on reasonable request.

\section{Authors' contributions}

HTH and WJW performed the research and analyzed the data; HTH, YTT, WJW, CML and YCL designed the research study and wrote the paper; YCL, $Y T$, and CML contributed essential reagents and tools. All authors read and approved the final manuscript.

\section{Ethics approval and consent to participate}

Not applicable.

\section{Consent for publication}

Not applicable.

\section{Competing interests}

The authors declare that they have no competing interests.

\section{Publisher's Note}

Springer Nature remains neutral with regard to jurisdictional claims in published maps and institutional affiliations.

\section{Author details}

${ }^{1}$ Faculty of Anesthesiology, School of Medicine, College of Medicine, Kaohsiung Medical University, Kaohsiung, Taiwan. ${ }^{2}$ Department of Anesthesia, Kaohsiung Municipal Ta-Tung Hospital, Kaohsiung, Taiwan. ${ }^{3}$ Department of Pharmacology, School of Medicine, College of Medicine,
Kaohsiung Medical University, 100 Shih-Chuan 1st Road, Kaohsiung 80708, Taiwan. ${ }^{4}$ Department of Nursing, Tzu Hui Institute of Technology, Pingtung County 92641, Taiwan.

Received: 22 February 2018 Accepted: 2 July 2018

Published online: 09 July 2018

\section{References}

1. Wu T, Tang M. Review of the effects of manufactured nanoparticles on mammalian target organs. J Appl Toxicol. 2018;38:25-40.

2. Donaldson $K$, Tran L, Jimenez LA, Duffin R, Newby DE, Mills N, MacNee W, Stone V. Combustion-derived nanoparticles: a review of their toxicology following inhalation exposure. Part Fibre Toxicol. 2005;2:10.

3. Peuschel H, Sydlik U, Grether-Beck S, Felsner I, Stockmann D, Jakob S, Kroker M, Haendeler J, Gotic M, Bieschke C, et al. Carbon nanoparticles induce ceramide- and lipid raft-dependent signalling in lung epithelial cells: a target for a preventive strategy against environmentally-induced lung inflammation. Part Fibre Toxicol. 2012;9:48.

4. Belade E, Armand L, Martinon L, Kheuang L, Fleury-Feith J, Baeza-Squiban A, Lanone S, Billon-Galland MA, Pairon JC, Boczkowski J. A comparative transmission electron microscopy study of titanium dioxide and carbon black nanoparticles uptake in human lung epithelial and fibroblast cell lines. Toxicol in Vitro. 2012;26:57-66.

5. Brown DM, Dickson C, Duncan P, Al-Attili F, Stone V. Interaction between nanoparticles and cytokine proteins: impact on protein and particle functionality. Nanotechnology. 2010;21:215104.

6. Elsabahy M, Wooley KL. Cytokines as biomarkers of nanoparticle immunotoxicity. Chem Soc Rev. 2013;42:5552-76.

7. Lin W, Huang W, Zhu T, Hu M, Brunekreef B, Zhang Y, Liu X, Cheng H, Gehring $U$, Li C, et al. Acute respiratory inflammation in children and black carbon in ambient air before and during the 2008 Beijing Olympics. Environ Health Perspect. 2011;119:1507-12.

8. Kamata H, Tasaka S, Inoue K, Miyamoto K, Nakano Y, Shinoda H, Kimizuka Y, Fujiwara H, Ishii M, Hasegawa N, et al. Carbon black nanoparticles enhance bleomycin-induced lung inflammatory and fibrotic changes in mice. Exp Biol Med (Maywood). 2011;236:315-24.

9. Vesterdal LK, Folkmann JK, Jacobsen NR, Sheykhzade M, Wallin H, Loft S, Moller P. Pulmonary exposure to carbon black nanoparticles and vascular effects. Part Fibre Toxicol. 2010;7:33.

10. Jackson $P$, Hougaard KS, Boisen AM, Jacobsen NR, Jensen KA, Moller $P$, Brunborg G, Gutzkow KB, Andersen O, Loft S, et al. Pulmonary exposure to carbon black by inhalation or instillation in pregnant mice: effects on liver DNA strand breaks in dams and offspring. Nanotoxicology. 2012;6:486-500.

11. Jacobsen NR, Moller P, Jensen KA, Vogel U, Ladefoged O, Loft S, Wallin H. Lung inflammation and genotoxicity following pulmonary exposure to nanoparticles in ApoE-/- mice. Part Fibre Toxicol. 2009;6:2.

12. Aam BB, Fonnum F. Carbon black particles increase reactive oxygen species formation in rat alveolar macrophages in vitro. Arch Toxicol. 2007:81:441-6.

13. Hussain S, Thomassen LC, Ferecatu I, Borot MC, Andreau K, Martens JA, Fleury J, Baeza-Squiban A, Marano F, Boland S. Carbon black and titanium dioxide nanoparticles elicit distinct apoptotic pathways in bronchial epithelial cells. Part Fibre Toxicol. 2010;7:10.

14. Nishanth RP, Jyotsna RG, Schlager JJ, Hussain SM, Reddanna P. Inflammatory responses of RAW 264.7 macrophages upon exposure to nanoparticles: role of ROS-NFkappaB signaling pathway. Nanotoxicology. 2011;5:502-16.

15. Jacobsen NR, White PA, Gingerich J, Moller P, Saber AT, Douglas GR, Vogel $\mathrm{U}$, Wallin H. Mutation spectrum in FE1-MUTA(TM) mouse lung epithelial cells exposed to nanoparticulate carbon black. Environ Mol Mutagen. 2011; $52: 331-7$

16. Schreiber N, Strobele M, Kopf J, Hochscheid R, Kotte E, Weber P, Hansen T, Bockhorn $\mathrm{H}$, Muller B. Lung alterations following single or multiple low-dose carbon black nanoparticle aspirations in mice. J Toxicol Environ Health A. 2013;76:1317-32.

17. Scoditti E, Nestola A, Massaro M, Calabriso N, Storelli C, De Caterina R, Carluccio MA. Hydroxytyrosol suppresses MMP-9 and COX-2 activity and expression in activated human monocytes via PKCalpha and PKCbeta1 inhibition. Atherosclerosis. 2014;232:17-24.

18. Yan F, Li W, Jono H, Li Q, Zhang S, Li JD, Shen H. Reactive oxygen species regulate Pseudomonas aeruginosa lipopolysaccharide-induced MUC5AC mucin expression via PKC-NADPH oxidase-ROS-TGF-alpha signaling 
pathways in human airway epithelial cells. Biochem Biophys Res Commun 2008;366:513-9.

19. Lin CC, Hsieh HL, Shih RH, Chi PL, Cheng SE, Chen JC, Yang CM. NADPH oxidase 2-derived reactive oxygen species signal contributes to bradykinininduced matrix metalloproteinase-9 expression and cell migration in brain astrocytes. Cell Commun Signal. 2012;10:35.

20. Wilhelmi V, Fischer U, Weighardt H, Schulze-Osthoff K, Nickel C, Stahlmecke B, Kuhlbusch TA, Scherbart AM, Esser C, Schins RP, et al. Zinc oxide nanoparticles induce necrosis and apoptosis in macrophages in a p47phoxand Nrf2-independent manner. PLoS One. 2013;8:e65704.

21. Geys J, Nemery B, Moreno EA, Hoet PH. Cytotoxicity of SiO2 in A549 cells. Toxicol Appl Pharmacol. 2007;220:225. author reply 226

22. Hanagata N, Zhuang F, Connolly S, Li J, Ogawa N, Xu M. Molecular responses of human lung epithelial cells to the toxicity of copper oxide nanoparticles inferred from whole genome expression analysis. ACS Nano. 2011;5:9326-38.

23. Guadagnini R, Moreau K, Hussain S, Marano F, Boland S. Toxicity evaluation of engineered nanoparticles for medical applications using pulmonary epithelial cells. Nanotoxicology. 2015;9(Suppl 1):25-32.

24. Zong Y, Sun L, Liu B, Deng YS, Zhan D, Chen YL, He Y, Liu J, Zhang ZJ, Sun J, et al. Resveratrol inhibits LPS-induced MAPKs activation via activation of the phosphatidylinositol 3-kinase pathway in murine RAW 264.7 macrophage cells. PLoS One. 2012;7:e44107.

25. Sticozzi C, Cervellati F, Muresan XM, Cervellati C, Valacchi G. Resveratrol prevents cigarette smoke-induced keratinocytes damage. Food Funct. 2014; 5:2348-56

26. Shih YT, Chen PS, Wu CH, Tseng YT, Wu YC, Lo YC. Arecoline, a major alkaloid of the areca nut, causes neurotoxicity through enhancement of oxidative stress and suppression of the antioxidant protective system. Free Radic Biol Med. 2010;49:1471-9.

27. Cossarizza A, Baccarani-Contri M, Kalashnikova G, Franceschi C. A new method for the cytofluorimetric analysis of mitochondrial membrane potential using the J-aggregate forming lipophilic cation 5,5',6,6'tetrachloro-1,1',3,3'-tetraethylbenzimidazolcarbocyanine iodide (JC-1). Biochem Biophys Res Commun. 1993;197:40-5.

28. Brubacher JL, Bols NC. Chemically de-acetylated 2,7'dichlorodihydrofluorescein diacetate as a probe of respiratory burst activity in mononuclear phagocytes. J Immunol Methods. 2001;251:81-91.

29. Sen NP, Donaldson B. Improved colorimetric method for determining nitrate and nitrate in foods. J Assoc Off Anal Chem. 1978:61:1389-94.

30. Tseng YT, Hsu YY, Shih YT, Lo YC. Paeonol attenuates microglia-mediated inflammation and oxidative stress-induced neurotoxicity in rat primary microglia and cortical neurons. Shock. 2012;37:312-8.

31. Tseng YT, Jong YJ, Liang WF, Chang FR, Lo YC. The water extract of Liuwei dihuang possesses multi-protective properties on neurons and muscle tissue against deficiency of survival motor neuron protein. Phytomedicine. 2017:34:97-105.

32. Soto K, Garza KM, Murr LE. Cytotoxic effects of aggregated nanomaterials. Acta Biomater. 2007;3:351-8.

33. L'Azou B, Jorly J, On D, Sellier E, Moisan F, Fleury-Feith J, Cambar J, Brochard $P$, Ohayon-Courtes $C$. In vitro effects of nanoparticles on renal cells. Part Fibre Toxicol. 2008;5:22.

34. Park EJ, Kim H, Kim Y, Yi J, Choi K, Park K. Carbon fullerenes (C60s) can induce inflammatory responses in the lung of mice. Toxicol Appl Pharmacol. 2010:244:226-33.

35. Adcock IM, Caramori G, Barnes PJ. Chronic obstructive pulmonary disease and lung cancer: new molecular insights. Respiration. 2011;81:265-84.

36. Wu YL, Lin AH, Chen CH, Huang WC, Wang HY, Liu MH, Lee TS, Ru Kou Y. Glucosamine attenuates cigarette smoke-induced lung inflammation by inhibiting ROS-sensitive inflammatory signaling. Free Radic Biol Med. 2014;69:208-18.

37. LLiu W, Peng Y, Yin Y, Zhou Z, Zhou W, Dai Y. The Involvement of NADPH Oxidase-Mediated ROS in Cytokine Secretion from Macrophages Induced by Mycobacterium tuberculosis ESAT-6. Inflammation. 2014;37:880-92.

38. Mroz RM, Schins RP, Li H, Drost EM, Macnee W, Donaldson K. Nanoparticle carbon black driven DNA damage induces growth arrest and AP-1 and NFkappaB DNA binding in lung epithelial A549 cell line. J Physiol Pharmacol. 2007;58(Suppl 5):461-70.

39. Lee IT, Yang CM. Role of NADPH oxidase/ROS in pro-inflammatory mediators-induced airway and pulmonary diseases. Biochem Pharmacol. 2012;84:581-90.
40. Nishizuka $Y$. The molecular heterogeneity of protein kinase $C$ and its implications for cellular regulation. Nature. 1988;334:661-5.

41. Jiang F, Zhang Y, Dusting GJ. NADPH oxidase-mediated redox signaling: roles in cellular stress response, stress tolerance, and tissue repair. Pharmacol Rev. 2011;63:218-42.

42. Lin CC, Hsieh HL, Chi PL, Yang CC, Hsiao LD, Yang CM. Upregulation of COX-2/PEG by ET-1 Mediated Through Ca-Dependent Signals in Mouse Brain Microvascular Endothelial Cells. Mol Neurobiol. 2014;49:1256-69.

43. Boncoeur E, Bouvet GF, Migneault F, Tardif V, Ferraro P, Radzioch D, de Sanctis JB, Eidelman D, Govindaraju K, Dagenais A, et al. Induction of nitric oxide synthase expression by lipopolysaccharide is mediated by calciumdependent PKCalpha-beta1 in alveolar epithelial cells. Am J Physiol Lung Cell Mol Physiol. 2013;305:L175-84.

44. Brown DM, Stone V, Findlay P, MacNee W, Donaldson K. Increased inflammation and intracellular calcium caused by ultrafine carbon black is independent of transition metals or other soluble components. Occup Environ Med. 2000:57:685-91.

45. Chakraborti S, Roy S, Mandal A, Dey K, Chowdhury A, Shaikh S, Chakraborti T. Role of PKCalpha-p(38)MAPK-G(i)alpha axis in NADPH oxidase derived O(2)(.-)-mediated activation of CPLA(2) under U46619 stimulation in pulmonary artery smooth muscle cells. Arch Biochem Biophys. 2012;523:169-80.

46. Kairisalo M, Bonomo A, Hyrskyluoto A, Mudo G, Belluardo N, Korhonen L, Lindholm D. Resveratrol reduces oxidative stress and cell death and increases mitochondrial antioxidants and XIAP in PC6.3-cells. Neurosci Lett. 2011:488:263-6

47. Khurana S, Venkataraman K, Hollingsworth A, Piche M, Tai TC. Polyphenols: benefits to the cardiovascular system in health and in aging. Nutrients. 2013;5:3779-827.

48. Lee MK, Kang SJ, Poncz M, Song KJ, Park KS. Resveratrol protects SH-SY5Y neuroblastoma cells from apoptosis induced by dopamine. Exp Mol Med. 2007;39:376-84

49. Liu H, Ren J, Chen H, Huang Y, Li H, Zhang Z, Wang J. Resveratrol protects against cigarette smoke-induced oxidative damage and pulmonary inflammation. J Biochem Mol Toxicol. 2014;28:465-71.

50. Kheradmand F, You R, Hee Gu B, Cigarette Smoke CDB. DNA cleavage promote lung inflammation and emphysema. Trans Am Clin Climatol Assoc 2017;128:222-33.

51. Nosal R, Drabikova K, Jancinova V, Perecko T, Ambrozova G, Ciz M, Lojek A, Pekarova M, Smidrkal J, Harmatha J. On the molecular pharmacology of resveratrol on oxidative burst inhibition in professional phagocytes. Oxidative Med Cell Longev. 2014;2014:706269.

52. Chen F, Qian LH, Deng B, Liu ZM, Zhao Y, Le YY. Resveratrol protects vascular endothelial cells from high glucose-induced apoptosis through inhibition of NADPH oxidase activation-driven oxidative stress. CNS Neurosci Ther. 2013;19:675-81.

53. Tsai MH, Hsu LF, Lee CW, Chiang YC, Lee MH, How JM, Wu CM, Huang CL, Lee IT. Resveratrol inhibits urban particulate matter-induced COX-2/PGE2 release in human fibroblast-like synoviocytes via the inhibition of activation of NADPH oxidase/ROS/NF-kappaB. Int J Biochem Cell Biol. 2017:88:113-23.

\section{Ready to submit your research? Choose BMC and benefit from:}

- fast, convenient online submission

- thorough peer review by experienced researchers in your field

- rapid publication on acceptance

- support for research data, including large and complex data types

- gold Open Access which fosters wider collaboration and increased citations

- maximum visibility for your research: over $100 \mathrm{M}$ website views per year

At BMC, research is always in progress.

Learn more biomedcentral.com/submissions 